\title{
Summer-autumn feeding ecology of Pied Flycatchers Ficedula hypolueca and Spotted Flycatchers Muscicapa striata: the importance of frugivory in a stopover area in north-west Iberia
}

\author{
ÁNGEL HERNÁNDEZ
}

\section{Summary}

North-west Iberia is a crucial stopover region for European populations of Pied Flycatchers Ficedula hypoleuca and Spotted Flycatchers Muscicapa striata during their summer-autumn migration. Both species are almost completely insectivorous during breeding in Europe and wintering in sub-Saharan Africa, but are known to consume fleshy fruits during summerautumn migration, though no detailed investigations have been carried out over long periods of time. In this study, the summer-autumn feeding ecology of Pied and Spotted Flycatchers in a stopover area in north-west Spain, with a landscape of hedgerows and irrigated meadows, was studied for five consecutive years (2002-2006). In general, the passage of both flycatcher species was noticeable from mid-August to the end of September, with a peak in the first ten days of September. The two flycatcher species consumed fruits throughout the stopover period in all years, with constant intensity of frugivory in time, though the importance of fruits was almost three times greater in the diet of Pied Flycatchers (c. $30 \%$ of feeding acts) than in that of Spotted Flycatchers (c. 10\% of feeding acts). Both species preferred Dogwood Cornus sanguinea fruits, but also ate Elder Sambucus nigra berries and Bramble Rubus spp. drupelets. The high level of selection of Dogwood fruits was probably linked to their high lipid content, an essential nutrient for fattening in long-distance migrant passerines. Hedgerows and wood edges in north-west Iberia are rich in fleshy fruits but threatened by intensive farming. Their conservation and restoration are proposed because they seem to be high-quality stopover habitats for partially frugivorous passerines during summer-autumn migration.

\section{Introduction}

During long-distance migration, the energy demands of migrating land birds increase and patterns of food resource availability vary, producing considerable changes in their general trophic ecology (Hutto 1985, Parrish 1997, Berthold 2001, Faaborg 2002, Long and Stouffer 2003, Newton 2008). In this respect, migrating land birds exhibit a high level of foraging and dietary flexibility (Herrera 1978, Gauthreaux 1982, Parrish 1997, 2000, McWilliams and Karasov 2001, Salewski and Jones 2006). It has been verified that bird species traditionally considered to be insectivorous, at least during the breeding period, may include fleshy fruits in their diet during autumn migration due, among other causes, to decreased availability of insects, and abundance and accessibility of fruits that are easily and rapidly digested, thus providing a profitable food source in terms of energy gain and fattening (Hernández 1993, 
Parrish 1997, 2000, Eggers 2000, Berthold 2001, Faaborg 2002, Bairlein 2003, Ottich and Dierschke 2003, Newton 2008).

Pied Flycatchers Ficedula hypoleuca and Spotted Flycatchers Muscicapa striata, two small (13-14 cm long, 14-16 g in weight) Palearctic passerines wintering south of the Sahara, are almost completely insectivorous during the breeding season (Davies 1977, Lundberg and Alatalo 1992, Cramp and Perrins 1993) and also in their African winter quarters (Cramp and Perrins 1993, Salewski et al. 2003, Salewski and Jones 2006), though there are fewer data available on the latter area. Both species consume fruits during summer-autumn passage, but information comes from very small sample sizes and short periods of time, usually one migration season (Ferns 1975, Bibby and Green 1980, Jordano 1981, 1982, 1987, Debussche and Isenmann 1989, Fuentes 1994, Hernández 1999). Most (> 75\%) of the global population of Pied Flycatchers breed in Europe and then fly en masse towards western Iberia, mainly to the northwest of the peninsula, a crucial stopover and fattening region, before overflying the Sahara apparently non-stop (Bernis 1963, Moreau 1972, Bibby and Green 1980, Veiga 1986, Cramp and Perrins 1993, Lundberg 1997, Hernández 1999, BirdLife International 2004, Flegg 2004, Newton 2008). As for the Spotted Flycatcher, approximately half of its global population breeds in Europe, and birds in western Europe then fly south, mainly to stopover sites in northwest Iberia, before going on to Africa where there is no evidence of their overflying the desert but of a gradual progression (Bernis 1963, Moreau 1972, Cramp and Perrins 1993, BirdLife International 2004).

Although Pied and Spotted Flycatchers are not endangered species, in recent decades they have undergone small or moderate declines the causes of which are not known, therefore their principal ecological requirements need to be investigated (Tomiałojć 1994, BirdLife International 2004). In this respect, the integration of important stopover sites in migratory land bird conservation plans is necessary, taking into account that their diet changes from insectivorous to partially or mainly frugivorous (Cantos and Tellería 1994, Hernández 1999, Parrish 2000, Faaborg 2002, Sapir et al. 2004). Food limitation at stopover sites may affect not only the migratory performance of birds, but also their subsequent reproduction or survival, with potential consequences on population levels (Newton 2008). In addition, frugivorous birds have an important role in dispersing seeds (Sekercioglu 2006), and obviously the mobility of birds increases during migration.

In the present study, the summer-autumn feeding ecology of Pied and Spotted Flycatchers at a stopover site in north-west Spain, in a very productive hedgerow habitat with great diversity of fleshy fruits, was examined for five consecutive years. In northern Spain, the edges of woods, hedgerows and other semi-natural habitats, where the highest densities of frugivorous birds are found, generally have greater diversity of fleshy-fruited plants than the better conserved woods (Herrera 2004, Hernández 2007). The study area is located in the Castilla y León region, where, according to data collected to the end of 2005, 4 million of the total 9.4 million hectares have been affected by land consolidation, thus increasing the size of agricultural and livestock holdings and reducing the shrub and tree vegetation separating them. Practically all the arable lands have been regrouped and recently areas of pastures and meadows of great environmental value bordering the mountains are also being regrouped, with a very negative effect on hedgerow habitats (Miranda and Rico 2007). In particular, the study area, lying in a zone of transition to the Cantabrian mountain range and in one of the most impressive landscapes of hedgerows and meadows in the region, has been threatened by land consolidation since 1990 (Hernández 1998), though this has still not occurred.

Specifically, the following aspects were analysed: 1 ) comparative abundance and density of both flycatcher species; 2) relative importance of insects and fruits in their diet; 3) foraging behaviour used to obtain insects and fruits; and 4) fruit diet and fruit selection. Intra- and inter-annual temporal variations in these aspects and differences between the two flycatcher species were also taken into account. Types of fruits consumed by flycatchers were compared with those consumed by other frugivorous passerines in the same area and on the same study dates. 


\section{Methods}

\section{Study area}

The total area covers 78 ha but only small subareas ( $18-42$ ha) were covered on each sampling day. The study area is located in the Torío river valley $\left(42^{\circ} 43^{\prime}-42^{\circ} 44^{\prime} \mathrm{N}, 5^{\circ} 30^{\prime}-5^{\circ} 31^{\prime} \mathrm{W}, 900-\right.$ $1000 \mathrm{~m}$ a.s.l.) in the León province, north-west Spain, and forms part of the Supramediterranean bioclimatic stage in the Mediterranean biogeographic region, but is very near the Eurosiberian region. During the study period (2002-2006) and time of year (16 August-30 September), the weather was generally warm $\left(\right.$ c. $23^{\circ} \mathrm{C}$ mean maximum and $10^{\circ} \mathrm{C}$ mean minimum) with intermittent rainfall (c. $20 \%$ of days). The principal landscape is composed of hedgerows that separate irrigated meadows, bordered by riparian woodland on one side and Pyrenean Oak Quercus pyrenaica woods on the other. Estimated hedgerow density is $3.3 \mathrm{~km}$ per to ha.

Eighteen native plant species (shrubs, trees, climbers) bear fleshy fruit in the hedgerows in the study area, taking the multispecific complexes of Rubus brambles and Rosa roses to be one species in each case, but only nine of them have ripe fruit between mid-August and the end of September (Purging Buckthorn Rhamnus catharticus, Brambles Rubus spp. - above all Blackberry R. ulmifolius, and Dewberry R. caesius, Blackthorn Prunus spinosa, Hawthorn Crataegus monogyna, Gooseberry Ribes uva-crispa, Dogwood Cornus sanguinea, White Bryony Bryonia cretica, Elder Sambucus nigra, and Honeysuckle Lonicera periclymenum), Purging Buckthorn and Gooseberry shrubs being very scarce. Although their fruits usually ripen late, ripe Privet Ligustrum vulgare and Guelder Rose Viburnum opulus fruits can sometimes be seen in September during hotter years. The hedgerows vary considerably in height but shrubs and tall trees whose height has not been reduced by pruning are abundant. The width of some hedgerows has been reduced by pruning to stop them from expanding into the meadows, but others are less manipulated and can grow to over $3 \mathrm{~m}$ wide.

\section{Data collection}

The study area was visited for five consecutive years (2002-2006) to estimate abundance and observe the foraging behaviour and food items consumed by Pied and Spotted Flycatchers in summer-autumn. Sampling was carried out on 48 days in total (per year: 10 days in 2002, 17 in 2003, six in 2004, nine in 2005, and six in 2006; per fortnight: on 18 days during 16-31 August, 16 during $1-15$ September, and 14 during 16-30 September) though data on all aspects of the study were not collected every day. At least one visit was made during each fortnight every year. Pied and Spotted Flycatchers do not breed in the study area. Although individuals of both species can be seen in the first fortnight in August and Pied Flycatchers even at the end of July, their passage is not noticeable until the second fortnight in August and continues so until the second fortnight in September, very few being recorded at the beginning of October. Sampling was carried out in the morning, over a mean period of five hours a day between o6hoo-12hoo (solar time) when migrating flycatchers show high foraging activity (Ferns 1975, Bibby and Green 1980, pers. obs.).

Data corresponding to 2003-2006 were used to estimate the temporal variation in compared abundance of both flycatcher species. In 2002 their foraging behaviour was studied but the population was not censused; thus 38 days were considered, on each of which a subarea varying in size (18-42 ha) was visited by slowly walking around all the hedgerows and recording all flycatchers seen or heard. Data for 2004-2006 were used to estimate the temporal variation in density (birds per 10 ha), when the same subarea ( 24 ha) was visited; thus 21 days were considered and abundance figures obtained as above were used; the results for density are shown in 1o-day intervals.

To estimate the relative importance of insects and fruits in the diet, and to analyse the foraging techniques of the two flycatcher species, as well as their temporal variations, data corresponding 
to all sampling days except for one in 2002 and part of another in the same year when data were recorded for consumed fruits but not for captured insects, were used; so 46 days and part of another were considered, when foraging behaviour was studied following each bird until it had carried out a maximum of three feeding acts to avoid pseudoreplication. Sometimes only a single foraging observation was obtained per bird as the flycatchers occasionally switched to a distant perch or perched on a concealed branch (e.g. on the other side of the hedgerow) after the first observation. A record was made of whether the food item was an insect or a fruit, whether the insect was captured on the ground or in flight and whether the fruit was removed while the bird was perched or in flight.

In feeding acts involving insects it was often impossible to verify a successful capture, especially in the case of small insects, so failed attempts were not subtracted and neither were captured insects identified. In feeding acts involving fruits only those that had actually been eaten were considered and it was always possible to identify the fruit species. Flycatchers behaved like dispersers, swallowing each fruit whole. In the case of large composite Rubus bramble fruits, they ate an individual drupelet during each feeding act. The apparent overestimation of the importance of insects (feeding attempts) in comparison with fruits (actually eaten) was probably compensated for by the fact that the search for and capture of insects in thick foliage, particularly tall trees, was underestimated in samplings due to difficulties in observation; however, most of the fruits were usually removed from the outer, middle and lower parts of the shrubs (pers. obs.). So it was assumed that the data set reflected the true diet.

Data corresponding to the 48 sampling days were used to estimate the number of fruits eaten per feeding visit and variation in fruit consumption in the morning (percentages of fruits eaten during the 06 hoo-08hoo, 08 hoo-10hoo, and 10hoo-12hoo intervals, out of the total fruits eaten). When a bird ate at least one fruit, this was considered to be a feeding visit.

To estimate differences between the fruit diet of the two flycatcher species and other frugivorous passerines, with regard to plant species involved, data for the 48 sampling days were used, and only feeding visits were considered as there was not enough time during sampling to record the number of fruits eaten per feeding visit by frugivorous birds that were not flycatchers. Data corresponding to feeding visits were also used to estimate the level of selection of fruit species by each bird species using the Jacobs (1974) index: $S=(v-a) /(v+a-2 v a)$, where $v$ is the proportion of feeding visits by a given bird species to a given plant species, in relation to the total number of feeding visits by that bird species, and $a$ is the proportion of availability of that plant species in relation to total availability of plants with ripe fleshy fruits. This index varies between -1 (maximum negative selection) and $I$ (maximum positive selection), with a value of o if there is no selection $(v=a)$. Availability of different plant species was estimated using data obtained during eight additional sampling days within the period 28 September-15 October 2004, when approximately $9 \mathrm{~km}$ of hedgerows were covered (c. 35\% of all the hedgerows evenly distributed in the study area), recording the qualitative occurrence but not the number of individuals of each plant species (shrubs, trees, climbers) in fragments of $2 \mathrm{~m}$ long ( $n=330$ fragments) situated every $25 \mathrm{~m}$ (modified from Hernández and Alegre 1991). Thus $a$ is the proportion of occurrence of a given plant species in relation to the total occurrences of plant species bearing ripe fruits during the period of bird migration considered (16 August31 September). $S$ was only calculated for bird species with over 20 recorded feeding visits, and the Guelder Rose was not included in the calculations as its fruits very rarely ripen during this period.

\section{Statistical analysis}

The chi-square test $\left(\chi^{2}\right)$, with Yates correction, was used to compare series of frequencies, and $t$-test to compare two means. Standard deviation (SD) was estimated as a measurement of dispersion. $P<0.05$ was considered statistically significant. 


\section{Results}

\section{Compared abundance and density in flycatchers}

A total of 396 Pied Flycatchers (78 in 2003, 55 in 2004, 187 in 2005, and 76 in 2006) and 398 Spotted Flycatchers (113, 51, 128, and 106, respectively) were recorded (Table 1). In the second fortnight in August in two years Pied Flycatchers represented $<30 \%$ and Spotted Flycatchers $>70 \%$ of the total number of flycatchers, and in the other two years the two species had similar values $(<60 \%$ for both); in the first fortnight in September values were similar for the two species $(<60 \%$ for both) every year; in the second fortnight in September, Pied Flycatchers represented $>60 \%$ every year and Spotted Flycatchers $<40 \%$, and Pied Flycatchers represented $>70 \%$ and Spotted Flycatchers $<30 \%$ in three of the study years. Considering all years together, there were significant differences between the two species in fortnightly abundance $\left(\chi_{2}^{2}=44.5, P<0.001\right)$, Spotted Flycatchers having greater comparative importance in the second fortnight in August and Pied Flycatchers in the second fortnight in September. The density of both flycatcher species increased progressively in August and continued to do so until the first ten days in September, maximum values being 16.3 Pied Flycatchers per 10 ha in 2005 and 13.3 Spotted Flycatchers per 10 ha in 2006, and then decreased progressively until the end of September (Figure 1).

\section{Relative importance of insects and fruits in the diet of flycatchers, and foraging techniques}

A total of 536 feeding acts by Pied Flycatchers ( 170 in 2002, 63 in 2003, 31 in 2004, 180 in 2005, and 92 in 2006) and 698 (157, 149, 43, 171, and 178, respectively) by Spotted Flycatchers were recorded (Table 2). For Pied Flycatchers and considering the three fortnights together, there were significant differences between years in the relative importance of insects and fruits $\left(\chi_{4}^{2}=14.0\right.$, $P<$ o.01), although insects were always predominant (66.7-88.0\% of feeding acts), and between years in method of capture $\left(\chi_{4}^{2}=13.1, P<0.05\right)$, though capture in flight was always more common $(76.5-100 \%)$. There were no significant differences for this flycatcher species in the remaining comparisons (between years considering the three fortnights together and between fortnights considering the five years together): between fortnights in importance of insects and fruits (71.8-73.6\% of insects), between fortnights in the method used to capture insects (in flight $84.2-89.7 \%$ ), between years in techniques used to obtain fruits (in flight $66.7-90.9 \%$ ), or between fortnights in techniques used to obtain fruits (in flight $75.9-81.4 \%)\left(\chi^{2}, P>0.05\right.$ in all cases). There were no significant differences for the Spotted Flycatcher between years or fortnights in any case, insects always being more important than fruits $(88.5-93.0 \%$ according to the year, 88.6-90.4\% according to the fortnight), most insects being captured in flight (94.7$100 \%$ according to the year, $97 \cdot 3-98.9 \%$ according to the fortnight), and most fruits being

Table 1. Comparative abundance of Pied (PiFly) and Spotted (SpFly) Flycatchers in each fortnight during the period 2003-2006 expressed as the number of individuals detected. 2FAug: second fortnight in August: 16-31 August. 1FSep: first fortnight in September: $1-15$ September. 2FSep: second fortnight in September: $16-30$ September.

\begin{tabular}{|c|c|c|c|c|c|c|c|c|c|c|c|c|}
\hline & \multicolumn{3}{|l|}{2003} & \multicolumn{3}{|l|}{2004} & \multicolumn{3}{|l|}{2005} & \multicolumn{3}{|l|}{2006} \\
\hline & 2FAug & IFSep & 2FSep & 2FAug & IFSep & 2FSep & 2FAug & IFSep & 2FSep & 2FAug & IFSep & 2FSep \\
\hline PiFly & 29 & 33 & 16 & 25 & 22 & 8 & 33 & 93 & 61 & 15 & 42 & 19 \\
\hline SpFly & 70 & 40 & 3 & 19 & 27 & 5 & 31 & 77 & 20 & 36 & 62 & 8 \\
\hline Total & 99 & 73 & 19 & 44 & 49 & 13 & 64 & 170 & 81 & 51 & 104 & 27 \\
\hline
\end{tabular}




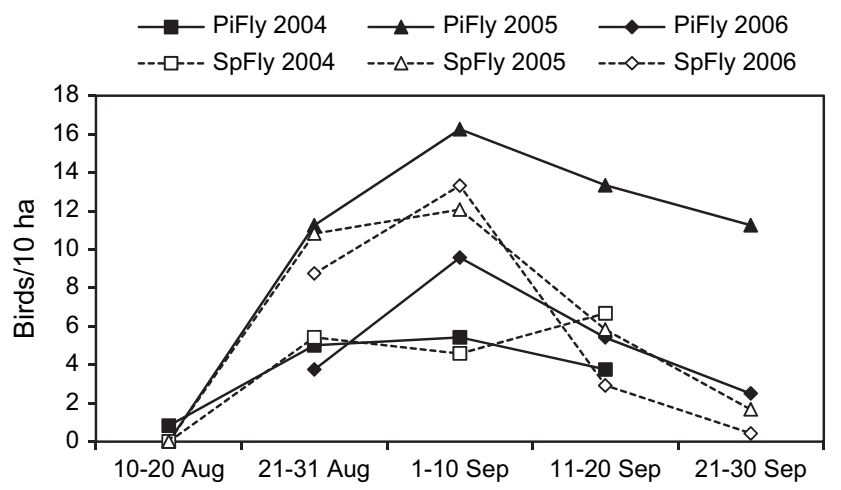

Figure 1. Pied (PiFly) and Spotted (SpFly) Flycatcher density during the period 2004-2006. The highest recorded value was considered for each 1o-day period.

obtained in flight (44.4-100\% according to the year, 50.0-77.3\% according to the fortnight) $\left(\chi^{2}, P>0.05\right.$ in all cases).

On comparing the two flycatcher species and considering all feeding acts together, the Pied Flycatcher was more frugivorous than the Spotted Flycatcher $(27.4 \%$ in contrast to $10.2 \%)\left(\chi_{1}^{2}=\right.$ 60.9, $P<0.001)$, the Pied Flycatcher caught more insects on the ground than the Spotted Flycatcher (14.1\% and $2.4 \%$ respectively) $\left(\chi_{1}^{2}=49.8, P<0.001\right)$, and the Spotted Flycatcher

Table 2. Insects and fruits in the diet of Pied and Spotted Flycatchers in each fortnight, and foraging techniques, during the period 2002-2006. Insect numbers are feeding attempts on the ground or in flight, and fruit numbers are fruits eaten when the bird was perched or in flight. 2FAug, 1FSep, 2FSep: as in Table 1.

\begin{tabular}{|c|c|c|c|c|c|c|c|c|}
\hline & \multicolumn{4}{|c|}{ Pied Flycatcher } & \multicolumn{4}{|c|}{ Spotted Flycatcher } \\
\hline & \multicolumn{2}{|l|}{ Insect } & \multicolumn{2}{|l|}{ Fruit } & \multicolumn{2}{|l|}{ Insect } & \multicolumn{2}{|l|}{ Fruit } \\
\hline & Ground & Flight & Perched & Flight & Ground & Flight & Perched & Flight \\
\hline \multicolumn{9}{|l|}{2002} \\
\hline 2F Aug & 1 & 10 & 2 & 3 & $\mathrm{o}$ & 11 & $\mathrm{o}$ & 1 \\
\hline IF Sep & 8 & 53 & 7 & 25 & 3 & 84 & 6 & 6 \\
\hline 2F Sep & 5 & 39 & 4 & 13 & $\mathrm{o}$ & 41 & 4 & 1 \\
\hline \multicolumn{9}{|l|}{2003} \\
\hline 2F Aug & 1 & 19 & 1 & 11 & 1 & 88 & 2 & 8 \\
\hline IF Sep & 1 & 18 & 2 & 5 & $\mathrm{o}$ & 42 & 2 & 2 \\
\hline 2F Sep & $\mathrm{o}$ & 3 & 1 & 1 & $\mathrm{o}$ & 4 & $\mathrm{o}$ & $\mathrm{o}$ \\
\hline \multicolumn{9}{|l|}{2004} \\
\hline 2F Aug & o & 5 & $\mathrm{o}$ & 1 & $\mathrm{o}$ & 15 & $\mathrm{o}$ & $\mathrm{o}$ \\
\hline IF Sep & o & 10 & 2 & 1 & $\mathrm{o}$ & 23 & o & 3 \\
\hline 2F Sep & o & 7 & 1 & 4 & o & 2 & o & o \\
\hline \multicolumn{9}{|l|}{2005} \\
\hline 2F Aug & 4 & 19 & 3 & 6 & 1 & 32 & 3 & 1 \\
\hline IF Sep & 9 & 57 & 5 & 22 & 6 & 80 & 3 & 6 \\
\hline $\begin{array}{l}2 \mathrm{~F} \mathrm{Sep} \\
2006\end{array}$ & 7 & 32 & 2 & 14 & 1 & 32 & 2 & 4 \\
\hline 2F Aug & 2 & 17 & 1 & 1 & 3 & 55 & o & 7 \\
\hline IF Sep & 10 & 25 & o & 6 & o & 90 & 3 & 6 \\
\hline 2F Sep & 7 & 20 & o & 3 & $\mathrm{o}$ & 13 & o & 1 \\
\hline Total & 55 & 334 & 31 & 116 & 15 & 612 & 25 & 46 \\
\hline
\end{tabular}


removed a higher percentage of fruits when perched than the Pied Flycatcher (35.2\% and 21.1\% respectively) $\left(\chi_{1}^{2}=4.29, P<0.05\right)$.

Pied Flycatchers obtained a total of 156 fruits on 130 feeding visits and Spotted Flycatchers 83 fruits on 67 feeding visits. Considering Dogwood alone, which accounted for $>80 \%$ of feeding visits to plants by both flycatcher species, there were no significant interspecific differences in the number of fruits taken on each feeding visit (Pied Flycatcher: $1.15 \pm 0.36$ fruits, range $1-2$, $n=108$ feeding visits; Spotted Flycatcher: $1.23 \pm 0.46$ fruits, range $1-3, n=64$ feeding visits; $t=-1.37, P>0.05)$. Other fruit species were not analysed due to the small sample size.

Fruit consumption by both flycatcher species decreased significantly throughout the morning, considering fruits consumed during the three intervals and expected values at a 1:1:1 ratio (Pied Flycatcher: $\chi_{2}^{2}=18.8, P<0.001$; Spotted Flycatcher: $\chi_{2}^{2}=10.4, P<0.01$ ) (Figure 2). Almost half of the fruits eaten by Pied Flycatchers (69 of 156, 44.2\%) and Spotted Flycatchers (40 of 83, $48.2 \%$ ) were obtained during the o6hoo-o8hoo interval. There were no significant differences between the two flycatcher species with regard to the number of fruits consumed in each time interval $\left(\chi_{2}^{2}=0.83, P>0.05\right)$.

\section{Fruit diet and fruit selection}

A total of 508 feeding visits by 12 bird species (nine seed dispersers and three seed eaters) to eight fleshy-fruited plant species were recorded, but only seven bird species, all seed dispersers, made more than 20 feeding visits each (European Robin Erithacus rubecula, Common Blackbird Turdus merula, Song Thrush Turdus philomelos, Garden Warbler Sylvia borin, Blackcap Sylvia atricapilla, Pied Flycatcher, and Spotted Flycatcher) (Table 3). The most visited plants were Dogwood, Elder and Brambles. Considering all the years and fortnights together, a significant association was observed between bird species and number of feeding visits to each plant species $\left(\chi_{77}^{2}=876.3, P<0.001\right)$, and association was also significant, but close to non-significance, when only the two flycatcher species were compared $\left(\chi_{2}^{2}=6.62, P=0.044\right)$. European Robins, and particularly flycatchers, visited mostly Dogwood; Common Blackbirds mainly visited Blackthorn, Hawthorn and Brambles; Song Thrushes visited mostly Hawthorn; and Garden Warblers and Blackcaps mainly visited Elder. Apart from Dogwood (83.1\% of feeding visits by Pied Flycatchers and $95.5 \%$ by Spotted Flycatchers), flycatchers visited Brambles (13.1\% and

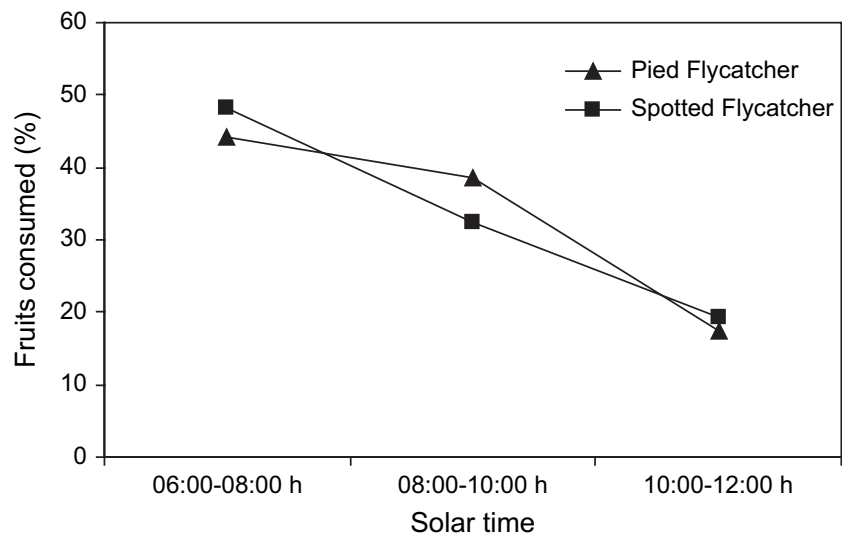

Figure 2. Variation in fruits consumed by Pied and Spotted Flycatchers throughout the morning during 16 August-30 September considering the period 2002-2006 as a whole. Percentages of the total number of fruits consumed by Pied $(n=156)$ and Spotted $(n=83)$ Flycatchers. 
Table 3. Number of feeding visits by frugivorous birds to fleshy-fruited plants in each fortnight during the period 2002-2006. During each feeding visit the bird ate at least one fruit. SD: seed disperser. SE: seed eater. 2FAug, IFSep, 2FSep: as in Table 1.

\begin{tabular}{|c|c|c|c|c|c|c|c|c|c|c|c|c|}
\hline & $\begin{array}{l}\text { European } \\
\text { Robin } \\
\text { (SD) }\end{array}$ & $\begin{array}{l}\text { Common } \\
\text { Redstart } \\
\text { (SD) }\end{array}$ & $\begin{array}{l}\text { Common } \\
\text { Blackbird } \\
\text { (SD) }\end{array}$ & $\begin{array}{l}\text { Song } \\
\text { Thrush } \\
\text { (SD) }\end{array}$ & $\begin{array}{l}\text { Common } \\
\text { Whitethroat } \\
\text { (SD) }\end{array}$ & $\begin{array}{l}\text { Garden } \\
\text { Warbler } \\
\text { (SD) }\end{array}$ & $\begin{array}{l}\text { Blackcap } \\
\text { (SD) }\end{array}$ & $\begin{array}{l}\text { Pied } \\
\text { Flycatcher } \\
\text { (SD) }\end{array}$ & $\begin{array}{l}\text { Spotted } \\
\text { Flycatcher } \\
\text { (SD) }\end{array}$ & $\begin{array}{l}\text { Blue } \\
\text { Tit } \\
\text { (SE) }\end{array}$ & $\begin{array}{l}\text { Common } \\
\text { Chaffinch } \\
\text { (SE) }\end{array}$ & $\begin{array}{l}\text { Common } \\
\text { Bullfinch } \\
\text { (SE) }\end{array}$ \\
\hline \multicolumn{13}{|c|}{ Bramble } \\
\hline${ }_{2} \mathrm{~F} \mathrm{Aug}$ & 2 & o & 5 & o & 1 & 4 & 2 & 7 & 2 & o & o & o \\
\hline ¡F Sep & 3 & o & 8 & o & 1 & 7 & 6 & 6 & o & 2 & o & o \\
\hline 2F Sep & 10 & o & 4 & o & o & I & 9 & 4 & o & 1 & o & o \\
\hline \multicolumn{13}{|c|}{ Blackthorn } \\
\hline${ }_{2} \mathrm{~F} \mathrm{Aug}$ & o & o & 10 & 1 & o & o & o & o & o & o & o & o \\
\hline IF Sep & o & o & 12 & o & o & o & o & o & o & o & o & o \\
\hline 2F Sep & o & o & 3 & o & o & o & o & o & o & o & o & o \\
\hline \multicolumn{13}{|c|}{ Hawthorn } \\
\hline 2F Aug & o & o & 0 & o & o & o & o & o & o & o & o & o \\
\hline IF Sep & o & o & 11 & 10 & o & o & o & o & o & o & o & o \\
\hline 2F Sep & o & o & 7 & 14 & o & o & o & o & o & o & o & o \\
\hline \multicolumn{13}{|c|}{ Dogwood } \\
\hline 2F Aug & 12 & 1 & 5 & 2 & o & 3 & 3 & 20 & 28 & o & o & o \\
\hline IF Sep & 11 & o & 1 & 2 & o & 3 & 8 & 55 & 26 & o & o & o \\
\hline 2 F Sep & 3 & o & 5 & 2 & o & 1 & 12 & 33 & 10 & o & o & o \\
\hline \multicolumn{13}{|c|}{ White Bryony } \\
\hline${ }_{2} \mathrm{~F} \mathrm{Aug}$ & o & o & o & o & o & o & 3 & o & o & o & o & o \\
\hline IF Sep & o & o & o & o & o & o & o & o & o & o & o & o \\
\hline 2 F Sep & o & o & o & o & o & o & o & o & o & o & o & o \\
\hline \multicolumn{13}{|l|}{ Elder } \\
\hline${ }_{2} \mathrm{~F} \mathrm{Aug}$ & 1 & o & 4 & o & o & 8 & 29 & 2 & o & o & o & o \\
\hline IF Sep & o & o & o & o & o & 15 & 25 & 2 & 1 & o & o & o \\
\hline${ }_{2}$ F Sep & o & o & o & 1 & o & 2 & 17 & 1 & o & o & o & o \\
\hline \multicolumn{13}{|c|}{ Honeysuckle } \\
\hline${ }_{2} \mathrm{~F}$ Aug & o & o & o & o & o & o & 1 & o & o & o & o & o \\
\hline IF Sep & o & o & o & o & o & o & o & o & o & o & o & 1 \\
\hline${ }_{2}$ F Sep & o & o & o & o & o & o & 3 & o & o & o & I & 1 \\
\hline \multicolumn{13}{|c|}{ Guelder Rose } \\
\hline${ }_{2} \mathrm{~F} \mathrm{Aug}$ & o & o & o & o & o & o & o & o & o & o & o & o \\
\hline IF Sep & o & o & o & o & o & o & o & o & o & o & o & o \\
\hline${ }_{2}$ F Sep & o & o & o & o & o & $\mathrm{o}$ & 1 & o & o & o & o & o \\
\hline Total & 42 & 1 & 75 & 22 & 2 & 44 & 119 & 130 & 67 & 3 & $I$ & 2 \\
\hline
\end{tabular}


$3.0 \%$ respectively) and Elder (3.8\% and $1.5 \%$ respectively). In a more detailed analysis for flycatcher species, there were no significant differences between years (considering the three fortnights together) or between fortnights (considering the five years together) in the number of feeding visits to each plant, for either bird species $\left(\chi^{2}, P>0.05\right.$ in all cases).

In the sampling of hedgerow plants, 27 species were detected, considering the multispecific complexes of Rubus brambles, Rosa roses, Populus poplars, and Salix willows to be a single species in each case, and 18 of these produced fleshy fruits. A total of 741 occurrences were recorded on the seven plant species which regularly offer ripe fruits between mid August and the end of September, Brambles (294 occurrences, 39.7\%, $a=0.397$ ), Blackthorn (140 occurrences, $18.9 \%, a=0.189$ ), Hawthorn (126 occurrences, 17.0\%, $a=0.170$ ), and Dogwood (125 occurrences, $16.9 \%, a=0.169$ ) being the most predominant (Table 4). Pied and Spotted Flycatchers selected Dogwood very positively $(S>0.9)$, and Elder was positively selected by Pied Flycatchers $(S=0.42)$ and visited by Spotted Flycatchers according to availability $(S \approx 0)$ (Table 4$)$. Both flycatcher species negatively selected Brambles $(S<-0.6)$ and did not make feeding visits to Blackthorn, Hawthorn, White Bryony or Honeysuckle $(S=-1)$.

The plant species most positively selected $(S \geq 0.3)$ by other bird species were Dogwood by European Robins; Elder and Blackthorn by Common Blackbirds; Hawthorn, Elder and Dogwood by Song Thrushes; and Elder by Garden Warblers and Blackcaps. Dogwood and Elder were the only plant species positively selected or visited according to availability, and not negatively selected, by all the principal frugivorous bird species.

\section{Discussion}

\section{Compared abundance and density in flycatchers}

Pied and Spotted Flycatchers were summer-autumn migrants in the study area, their passage being noticeable from the last ten days in August and with a density peak in the first ten days of September. Generally, autumn departure of both species begins in Europe as early as the end of July or beginning of August, and in both species autumn migration phenology seems to coincide in the northern and central areas of the continent (Veiga 1986, Cramp and Perrins 1993, Flegg 2004). During the study period, the trend was towards greater comparative abundance of Spotted Flycatchers during stopover in the second fortnight in August, and of Pied Flycatchers in the

Table 4. Fruit selection by principal frugivorous bird species ( $S$ : Jacobs index) during 16 August-30 September considering the period 2002-2006 as a whole. $S$ varies between -1 (maximum negative selection) and I (maximum positive selection), with the value o if selection does not occur (plant species visited according to availability). See Table 3 for feeding visits by each bird species to each plant species. Availability of plant species with ripe fleshy fruits is expressed as the proportion of the total number $(n=$ 741) of qualitative occurrences of these species in the sampling units. The body weight in grams for each bird species appears in parentheses.

\begin{tabular}{lllllllll}
\hline Selection $(S)$ & \multicolumn{1}{c}{ Availability } & $\begin{array}{l}\text { European } \\
\text { Robin } \\
(16.5)\end{array}$ & $\begin{array}{l}\text { Common } \\
\text { Blackbird } \\
(90)\end{array}$ & $\begin{array}{l}\text { Song } \\
\text { Thrush } \\
(70)\end{array}$ & $\begin{array}{l}\text { Garden } \\
\text { Warbler } \\
(19)\end{array}$ & $\begin{array}{l}\text { Blackcap } \\
(19)\end{array}$ & $\begin{array}{l}\text { Pied } \\
\text { Flycatcher } \\
(14)\end{array}$ & $\begin{array}{l}\text { Spotted } \\
\text { Flycatcher } \\
(16)\end{array}$ \\
\hline Bramble & 0.397 & -0.08 & -0.38 & -1 & -0.27 & -0.59 & -0.63 & -0.91 \\
Blackthorn & 0.189 & -1 & 0.36 & -0.66 & -1 & -1 & -1 & -1 \\
Hawthorn & 0.170 & -1 & 0.21 & 0.79 & -1 & -1 & -1 & -1 \\
Dogwood & 0.169 & 0.78 & -0.08 & 0.30 & -0.04 & 0.09 & 0.92 & 0.98 \\
White Bryony & 0.021 & -1 & -1 & -1 & -1 & 0.09 & -1 & -1 \\
Elder & 0.016 & 0.20 & 0.55 & 0.49 & 0.97 & 0.98 & 0.42 & -0.03 \\
Honeysuckle & 0.038 & -1 & -1 & -1 & -1 & -0.06 & -1 & -1 \\
\hline
\end{tabular}


second fortnight in September, with similar abundance in the first fortnight in September, though the review by Tellería et al. (1999) for the Iberian peninsula simply indicates that the maximum passage of both species is in September.

There are not enough data on maximum values for flycatcher density in Spain and Portugal during summer-autumn migration to compare with the present study. In different types of forest (Fagus, Quercus, Pinus, Juniperus) in different areas in Spain located more towards the east than the study area, comparatively lower maximum densities were recorded in September (0.3-1.5 Pied Flycatchers and 0.3-3.0 Spotted Flycatchers per 1o ha, Zamora and Camacho 1984a, b, Obeso 1987, Costa 1993), however, in Pinus forests in south-west Spain (Costa 1984) and Quercus forests in central Portugal (Bibby and Green 1980) up to 26 and 42 Pied Flycatchers per Io ha, respectively, were recorded. These variations were probably due to differences in habitat quality and in the greater or shorter distance of the study areas from the main migration route of flycatchers through western Iberia.

\section{Relative importance of insects and fruits in the diet of flycatchers, and foraging techniques}

Pied and Spotted Flycatchers consumed fruit throughout the entire passage period in all the study years, with generally constant frugivory intensity over time, although the importance of fruits in their diet was almost three times greater for the Pied Flycatcher (c. $30 \%$ of feeding acts) than for the Spotted Flycatcher (c.10\%). Some studies on migrating Pied Flycatchers in the French Mediterranean region and in Quercus forests in northern and central Portugal simply indicate occasional fruit consumption at the end of summer (Ferns 1975, Bibby and Green 1980, Debussche and Isenmann 1989), but Jordano $(1981,1982,1987)$ found moderate values for fruit consumption by this species in different habitats in south-west Spain in summer-autumn (c. 20$35 \%$ average volume in fecal and regurgitated samples). Although there is less information for the Spotted Flycatcher, in south-west Spain it also seems to be less frugivorous during autumn migration (c. $2-15 \%$ average volume in fecal and regurgitated samples; Jordano 1981, 1987) than the Pied Flycatcher.

Pied and Spotted Flycatchers, in particular the latter, with large heads and bills and weak legs, are adapted to seizing large food items including insects and fruits in flight, and during autumn migration aerial foraging increases in stopover areas (almost always $>75 \%$ of feeding acts) in comparison with breeding areas (Ferns 1975, Davies 1977, Alatalo and Alatalo 1979, Bibby and Green 1980, Jordano 1981, Lundberg and Alatalo 1992, Cramp and Perrins 1993, Hernández 1999, this study). Both flycatcher species are similar in size and weight, but Pied Flycatchers have a comparatively stubbier bill than Spotted Flycatchers (Cramp and Perrins 1993) and this probably contributes to their consuming more fruit.

Migrating Pied and Spotted Flycatchers usually only consume one or two fruits each feeding visit (Hernández 1999, present study), probably because their small body size considerably limits the volume of food ingested, as verified in other studies of very small frugivorous bird species (e.g. Hernández 2003 for the European Robin). Pied and Spotted Flycatchers consumed more fruits very early in the morning, presumably because there were very few large active flying insects available at this time (Hernández 1995a for the study area in summer), but they did not stop eating fruits throughout the morning.

\section{Fruit diet and fruit selection}

Differences in the fruit diet composition of bird species were noticeable, and only two fruit species, Dogwood and Elder, were positively selected or visited according to availability by the seven main frugivorous species. Pied and Spotted Flycatchers preferred Dogwood fruits during the entire stopover period every year. Gape width and fruit size are limiting factors of the first order in seed-dispersing birds that normally swallow entire fruits (Jordano 2000, Herrera 2002, 
Alcántara and Rey 2003, pers. obs.), so Blackthorn and Hawthorn fruits, with a mean length and width of generally $>10 \mathrm{~mm}$ (Herrera 1987, Snow and Snow 1988), were only consumed by larger bird species, with high positive selection of Blackthorn fruits by Common Blackbirds and Hawthorn fruits by Song Thrushes. The other bird species (European Robin, Sylvia warblers and flycatchers) ate fruits from the rest of the plant species with a mean length and width of generally $<8 \mathrm{~mm}$ (Herrera 1987, Snow and Snow 1988), or small individual drupelets of Rubus fruits.

Such a high level of selection of Dogwood fruits by both flycatcher species was probably because of their high lipid content (c. $25 \%$ of the dry mass of pulp) and energy supply (c. $5 \mathrm{kcal} \mathrm{g}^{-1}$ of dry pulp), much higher than in other fruit species which did not exceed $7 \%$ and $4 \mathrm{kcal} \mathrm{g}^{-1}$, respectively, in any case (Debussche et al. 1987, Herrera 1987, Snow and Snow 1988). Preference for lipid-rich fruits was also found in other studies on migrating landbirds in Eurasia and North America (Stiles 1993, 2000, Izhaki 2002), and according to observations in different places in southern France and northern Iberia (Debussche and Isenmann 1989, Fuentes 1994, Hernández 1999), Dogwood fruits seem to be attractive for migrating Pied Flycatchers. Dogwood grows mostly in the northern half of Iberia, in moist soil in hedgerows and the edges of deciduous forests, its fruits ripen relatively early in summer and production is fairly constant year after year (Guitián et al. 1996, López 2004). It therefore probably plays an important part in fattening and energy gain in Pied and Spotted Flycatchers on autumn migration. Other fruits with a high lipid content, such as Terebinth Pistacia terebinthus and Lentisc Pistacia lentiscus (> $55 \%$ of the dry mass of pulp, Herrera 1987), are also preferred by migrating Pied Flycatchers in typical Mediterranean environments, from southern France to Andalusia (Jordano 1984, Debusssche and Isenmann 1989, Fuentes 1994). Fruit lipids can play an important role in forming fat reserves in migrating passerines, especially in moderately frugivorous species such as flycatchers that show slow food passage through the digestive tract and thus efficient lipid assimilation (Fuentes 1994, Berthold 2001, Bairlein 2003, Newton 2008).

Garden Warblers and a small number of Blackcaps, like flycatchers, were trans-Saharan migrants, with autumn passage through Spain occurring from the second fortnight in August and low to medium fattening in southern Europe (Rodríguez 1985, Cramp and Perrins 1993, Tellería et al. 1999). Both species consumed Dogwood fruits according to availability but selected elderberries very positively. Migrating Sylvia warblers and other passerine species are known to prefer elderberries, probably because of their high protein content (c. $18 \%$ of the dry mass of pulp, Herrera 1987) and small size, forming large racemes which makes them easily accessible and easy to swallow (Snow and Snow 1988, Boddy 1991, Hernández 1995b, Berthold 2001, Ottich and Dierschke 2003). Body mass gain in migrating birds is fundamentally the result of the combined effect of high energy intake provided by lipids and protein intake, the latter generally being more dependent on insects (Newton 2008).

\section{Concluding remarks: migrating flycatchers, fruits and conservation}

One hypothesis to partly explain why insectivorous bird species change to a fundamentally or partially frugivorous diet during migration is the lack of, or reduction in, preferred insect resources ('resource availability hypothesis') (Parrish 1997, Berthold 2001, Newton 2008). In the study area however, the hedgerows and wet meadows are situated very close to the river, and even the edges of nearby oak stands offer maximum availability of insects in summer and very high availability at the onset of autumn (Hernández et al. 1993, pers. obs.) and this did not stop Pied and Spotted Flycatchers from eating fruits regularly, also at times during the day when flying insects were most active. Favourable places for migrating landbirds are characterised by a prolonged stopover period and high bird density (Veiga 1986 for Pied Flycatchers; Newton 2008 for birds in general), as occurred in the study area. Fruits were probably consumed by flycatchers to optimise their net energy uptake for fattening. Currently, the 'energy assimilation hypothesis' best explains fruit consumption by migrating passerines, with an energetic advantage 
and more rapid increase in body mass thanks to omnivory rather than strict insectivory, though a large quantity of fruits needs to be consumed (Parrish 1997, Eggers 2000, Berthold 2001, Bairlein 2003, Newton 2008). Some fruit species frequently consumed by migrating flycatchers in Iberia, such as Dogwood in the present study, have a high energy content, only slightly lower than that of insects (c. $5 \mathrm{kcal} \mathrm{g}^{-1}$ dry pulp for Dogwood as previously indicated, in comparison with 5.2-6.8 $\mathrm{kcal} \mathrm{g}^{-1}$ dry weight for insects, according to Golley 1961, Avery 1971, Jordano 1981). Fruits are obtained more easily than insects because they are an immobile and predictable food source, concentrated in space and conspicuous. Their low fibre content enables more rapid digestion and high water content reduces the need to drink; all of which are advantageous factors for migrating passerines (Parrish 2000, Berthold 2001, Newton 2008).

Nevertheless, further research is necessary to establish whether the mixing of insects and fruit in the diet of migrating flycatchers really constitutes a population phenomenon, or whether only some individuals were specialised in eating fruits because they had previously fed at sites with few insects but abundant fruits on their migration route (C. J. Whelan pers. comm.). According to some physiological studies (Levey and Karasov 1989, 1992) and theoretical models based on physiology (Whelan et al. 2000), diet switching and strong specialization can increase the digestive efficiency of birds by optimal adjustment of the retention time of food in the gut.

Afro-Palearctic migrant birds have suffered a general population decrease over the last 35 years, including partially frugivorous passerines such as flycatchers, Garden Warbler, Common Whitethroat Sylvia communis and Common Redstart Phoenicurus phoenicurus, and research is needed on factors operating on passage areas (Berthold et al. 1998, Sanderson et al. 2006). In nonbreeding, migrating landbirds food is a worldwide key factor in habitat and microhabitat selection on the migration route of each species (e.g. Hutto 1985) and it has been verified that frugivorous birds select fruit-rich stopover sites (Parrish 2000, Sapir et al. 2004), which can be created in pastures and fields by planting suitable fruit shrubs and trees (Foster 2007). In northwest Iberia, a crucial stopover region for Pied and Spotted Flycatchers, the conservation and restoration of hedgerows and other habitats with abundant fleshy fruits, for example forest edges, are probably useful measures for maintaining the good health of European populations of these birds and other partially frugivorous migrant passerines, in line with the modern conservation strategy for the wider environment (see Tucker and Evans 1997).

\section{Acknowledgements}

This paper is a research contribution of the Ecology and Conservation of Flora and Fauna Group at Valladolid University, Spain. I thank José Luis Robles, Chris Whelan and an anonymous reviewer for their critical reading of the manuscript.

\section{References}

Alatalo, R. V. and Alatalo, R. H. (1979) Resource partitioning among a flycatcher guild in Finland. Oikos 23: 46-54.

Alcántara, J. M. and Rey, P. J. (2003) Conflicting selection pressures on seed size: evolutionary ecology of fruit size in a birddispersed tree, Olea europaea. J. Evol. Biol. 16: $1168-1176$.

Avery, R. A. (1971) Estimates of food consumption by the lizard Lacerta vivipara Jacquin. J. Anim. Ecol. 40: 351-365.
Bairlein, F. (2003) Nutritional strategies in migrating birds. Pp. $321-332$ in P. Berthold, E. Gwinner and E. Sonnenschein, eds. Avian migration. Berlin: Springer.

Bernis, F. (1963) Sobre migración de nuestros Passeriformes transaharianos. Ardeola 8: 41-119.

Berthold, P. (2001) Bird migration. A general survey. Second edition. Oxford: Oxford University Press. 
Berthold, P., Fiedler, W., Schlenker, R. and Querner, U. (1998) 25-year study of the population development of Central European songbirds: a general decline, most evident in long-distance migrants. Naturwissenschaften 85: 350-353.

Bibby, C. J. and Green, R. E. (1980) Foraging behaviour of migrant pied flycatchers, $F i$ cedula hypoleuca, on temporary territories. J. Anim. Ecol. 49: 507-521.

BirdLife International (2004) Birds in Europe: population estimates, trends and conservation status. Cambridge: BirdLife International.

Boddy, M. (1991) Some aspects of frugivory by bird populations using coastal dune scrub in Lincolnshire. Bird Study 38: 188199.

Cantos, F. J. and Tellería, J. L. (1994) Stopover fidelity of four migrant warblers in the Iberian Peninsula. J. Avian Biol. 25: 131134.

Costa, L. (1984) Composición de la comunidad de aves en pinares del Parque Nacional de Doñana (suroeste de España). Doñana Acta Vertebr. 11: 151-183.

Costa, L. (1993) Evolución estacional de la avifauna en hayedos de la montaña cantábrica. Ardeola 40: 1-11.

Cramp, S. and Perrins, C. M., eds. (1993) The birds of the western Palearctic. Vol. 7. Oxford: Oxford University Press.

Davies, N. B. (1977) Prey selection and the search strategy of the spotted flycatcher (Muscicapa striata): a field study on optimal foraging. Anim. Behav. 25: 1016-1033.

Debussche, M., Cortez, J. and Rimbault, I. (1987) Variation in fleshy fruit composition in the Mediterranean region: the importance of ripening season, life form, fruit type and geographical distribution. Oikos 49: 244-252.

Debussche, M. and Isenmann, P. (1989) Fleshy fruit characters and the choices of bird and mammal seed dispersers in a Mediterranean region. Oikos 56: 327-338.

Eggers, S. (2000) Compensatory frugivory in migratory Sylvia warblers: geographical responses to season length. J. Avian Biol. 31: $63-74$.

Faaborg, J. (2002) Saving migrants birds. Developing strategies for the future. Austin: University of Texas Press.
Ferns, P. N. (1975) Feeding behaviour of autumn passage migrants in north east Portugal. Ringing \& Migration 1: 3-11.

Flegg, J. (2004) Time to fly. Exploring bird migration. Thetford: British Trust for Ornithology.

Foster, M. S. (2007) The potential of fruit trees to enhance converted habitats for migrating birds in southern Mexico. Bird Conserv. Int. 17: 45-61.

Fuentes, M. (1994) Diets of fruit-eating birds: what are the causes of interspecific differences? Oecologia 97: 134-142.

Gauthreaux, S. A. Jr. (1982) The ecology and evolution of avian migration systems. Pp. 93-168 in D. S. Farner, J. R. King and K. C. Parkes, eds. Avian Biology. Vol. 6. Orlando: Academic Press.

Golley, F. B. (1961) Energy values of ecological materials. Ecology 42: 581-584.

Guitián, J., Guitián, P. and Navarro, L. (1996) Fruit set, fruit reduction, and fruiting strategy in Cornus sanguinea (Cornaceae). Am. J. Bot. 83: 744-748.

Hernández, A. (1993) Variación temporal en el consumo de frutos de arraclán (Frangula alnus) por aves en el valle del río Torío (Cordillera Cantábrica, noroeste de España). Ardeola 40: 21-26.

Hernández, A. (1995a) Comportamiento de caza del alcaudón dorsirrojo en verano: variación en el método y en la frecuencia de ataques durante el día, y relación con la disponibilidad de presas. Ardeola 42: 91-95.

Hernández, A. (1995b) Nota sobre los frutos consumidos por aves dispersantes de semillas en un seto del noroeste de España. Anales Jard. Bot. Madrid 53: 267-270.

Hernández, A. (1998) La concentración parcelaria del valle leonés del Torío condena a sus setos. Quercus 151: 46-47.

Hernández, A. (1999) Dieta frugívora de los Papamoscas Cerrojillos Ficedula hypoleuca en paso otoñal: revisión y datos inéditos. Butll. GCA 16: 53-6o.

Hernández, A. (2003) Variations in spindle Euonymus europaeus consumption by frugivorous birds during the fruiting season. Ardeola 50: 171-180.

Hernández, A. (2007) Alimentación de aves frugívoras en setos y bordes de bosque del norte de España: importancia de algunas 
especies de plantas en invierno y primavera. Ecología 21: 145-156.

Hernández, A. and Alegre, J. (1991) Estructura de la comunidad de paseriformes en setos de la provincia de León (noroeste de España). Doñana Acta Vertebr. 18: 237-250.

Hernández, A., Purroy, F. J. and Salgado, J. M. (1993) Variación estacional, solapamiento interespecífico y selección en la dieta de tres especies simpátricas de alcaudones Lanius spp. Ardeola 40: 143-154.

Herrera, C. M. (1978) Ecological correlates of residence and non-residence in a Mediterranean passerine bird community. J. Anim. Ecol. 47: 871-890.

Herrera, C. M. (1987) Vertebrate-dispersed plants of the Iberian Peninsula: a study of fruit characteristics. Ecol. Monogr. 57: 305331.

Herrera, C. M. (2002) Seed dispersal by vertebrates. Pp. $185-208$ in C. M. Herrera and O. Pellmyr, eds. Plant-animal interactions. An evolutionary approach. Oxford: Blackwell Science.

Herrera, C. M. (2004) Ecología de los pájaros frugívoros ibéricos. Pp. 127-153 in J. L. Tellería, ed. La ornitología hoy. Madrid: Editorial Complutense-SEO.

Hutto, R. L. (1985) Habitat selection by nonbreeding, migratory land birds. Pp. 455476 in M. L. Cody, ed. Habitat selection in birds. Orlando: Academic Press.

Izhaki, I. (2002) The role of fruit traits in determining fruit removal in east Mediterranean ecosystems. Pp. 161-175 in D. J. Levey, W. R. Silva and M. Galetti, eds. Seed dispersal and frugivory: ecology, evolution and conservation. Wallingford: CABI Publishing.

Jacobs, J. (1974) Quantitative measurement of food selection. A modification of forage ratio and Ivlev's electivity index. Oecologia 14: 413-417.

Jordano, P. (1981) Alimentación y relaciones tróficas entre los paseriformes en paso otoñal por una localidad de Andalucía central. Doñana Acta Vetrebr. 8: 103-124.

Jordano, P (1982) Migrant birds are the main seed dispersers of blackberries in southern Spain. Oikos 38: 183-193.

Jordano, P. (1984) Relaciones entre plantas y aves frugivoras en el matorral mediterrá- neo del área de Doñana. PhD Thesis. Seville: The University of Seville.

Jordano, P. (1987) Notas sobre la dieta no insectívora de algunos Muscicapidae. Ardeola 34: 89-98.

Jordano, P. (2000) Fruits and frugivory. Pp. 125-165 in M. Fenner, ed. Seeds. The ecology of regeneration in plant communities. Second edition. Wallingford: CABI Publishing.

Levey, D. J. and Karasov, W. H. (1989) Digestive responses of temperate birds switched to fruit or insect diets. Auk 106: 675-686.

Levey, D. J. and Karasov, W. H. (1992) Digestive modulation in a seasonal frugivore, the American robin (Turdus migratorius). Am. J. Physiol. 262: G711-G718.

Long, J. A. and Stouffer, P. C. (2003) Diet and preparation for spring migration in captive Hermit Thrushes (Catharus guttatus). Auk 120: 323-330.

López, G. (2004) Guía de los árboles y arbustos de la Península Ibérica y Baleares. Second edition. Madrid: Mundi-Prensa.

Lundberg, A. (1997) Pied Flycatcher Ficedula hypoleuca. Pp. 620-621 in E.J.M. Hagemeijer and M. J. Blair, eds. The EBCC atlas of European breeding birds: their distribution and abundance. London: Poyser.

Lundberg, A. and Alatalo, R. V. (1992) The Pied Flycatcher. London: Poyser.

McWilliams, S. R. and Karasov, W. H. (2001) Phenotypic flexibility in digestive system structure and function in migratory birds and its ecological significance. Comp. Biochem. Physiol., A 128: 579-593.

Miranda, B. and Rico, M. (2007) La agricultura de Castilla y León: situación actual y retos de futuro. Pp. 29-49 in J. A. GómezLimón, ed. El futuro de la agricultura en Castilla y León. Palencia: Centro Tecnológico Agrario y Agroalimentario.

Moreau, R. E. (1972) The Palaearctic-African bird migration systems. London and New York: Academic Press.

Newton, I. (2008) The migration ecology of birds. London: Academic Press.

Obeso, J. R. (1987) Comunidades de passeriformes en bosques mixtos de altitudes medias de la Sierra de Cazorla. Ardeola 34: 37-59. 
Ottich, I. and Dierschke, V. (2003) Exploitation of resources modulates stopover behaviour of passerine migrants. J. Ornithol. 144: 307-316.

Parrish, J. D. (1997) Patterns of frugivory and energetic condition in Nearctic landbirds during autumn migration. Condor 99: 681697.

Parrish, J. D. (2000) Behavioral, energetic, and conservation implications of foraging plasticity during migration. Stud. Avian Biol. 20: 53-70.

Rodríguez, M. (1985) Weights and fat accumulation of Blackcaps Sylvia atricapilla during migration through southern Spain. Ringing \& Migration 6: 33-38.

Salewski, V., Bairlein, F. and Leisler, B. (2003) Niche partitioning of two Palearctic passerine migrants with Afrotropical residents in their West African winter quarters. Behav. Ecol. 14: 493-502.

Salewski, V. and Jones, P. (2006) Palearctic passerines in Afrotropical environments: a review. J. Ornithol. 147: 192-201.

Sanderson, F. J., Donald, P. F., Pain, D. J., Burfield, I. J. and van Bommel, F. P. J. (2006) Long-term population declines in Afro-Palearctic migrant birds. Biol. Conserv. 131: 93-105.

Sapir, N., Abramsky, Z., Shochat, E. and Izhaki, I. (2004) Scale-dependent habitat selection in migratory frugivorous passerines. Naturwissenschaften 91: 544547 .

Sekercioglu, C. H. (2006) Increasing awareness of avian ecological function. Trends Ecol. Evol. 21: 464-471.
Snow, B. and Snow, D. (1988) Birds and berries. Calton: Poyser.

Stiles, E. W. (1993) The influence of pulp lipids on fruit preference by birds. Plant Ecol. 107-108: 227-235.

Stiles, E. W. (2000) Animals as seed dispersers. Pp. 111-124 in M. Fenner, ed. Seeds. The ecology of regeneration in plant communities. Second edition. Wallingford: CABI Publishing.

Tellería, J. L., Asensio, B. and Díaz, M. (1999) Aves ibéricas. Vol. 2. Madrid: Reyero.

Tomiałojć, L. (1994) Spotted Flycatcher Muscicapa striata. Pp. 404-405 in G. M. Tucker and M. F. Heath, eds. Birds in Europe: their conservation status. Cambridge: BirdLife International.

Tucker, G. M. and Evans, M. I. (1997) Habitats for birds in Europe: a conservation strategy for the wider environment. Cambridge: BirdLife International.

Veiga, J. P. (1986) Settlement and fat accumulation by migrant Pied Flycatchers in Spain. Ringing \& Migration 7: 85-98.

Whelan, C. J., Brown, J. S., Schmidt, K. A., Steele, B. B. and Willson, M. F. (200o) Linking consumer-resource theory and digestive physiology: application to diet shifts. Evol. Ecol. Res. 2: 911-934.

Zamora, R. and Camacho, I. (1984a) Evolución estacional de la comunidad de aves en un encinar de Sierra Nevada. Doñana Acta Vertebr. 11: 25-43.

Zamora, R. and Camacho, I. (1984b) Evolución estacional de la comunidad de aves en un robledal de Sierra Nevada. Doñana Acta Vertebr. 11: 129-150.

\section{ÁNGEL HERNÁNDEZ}

Department of Agroforestry, University of Valladolid, Avenida de Madrid 44, 34071 Palencia, Spain.e-mail:ahernan@agro.uva.es

Received 20 May 2008; revision accepted 15 October 2008 